\title{
特集 FDP
}

\section{小児科領域における FDP}

山田兼雄 ${ }^{*}$

\section{はじめに}

小児の FDP を論ずる場合に問題となること は，新生児期には生理的状態においてすでにか なり多量の FDP が血中に存在するということ である。この点が他の領域と異なり注意すべき 点である.

それで病的状態の場合には, 新生児の生理的 特徵をさらに上回って FDP が動くことにな る。そして FDP に影響をおよ括す病的状態と いらのは小児科領域でもやはり DIC であるこ とは変りない。

われわれが重点をおいて検討してきた呼吸障 害症候群(Respiratory distress syndrome, RDS) の FDP ならびにその類縁物質の動態は，興味 深いものがある。これらの成績は，小児科以外 の他の領域においても共通のものとしていろい ろと示唆を与える点もあるが，また一方新生児 期といらことで独得の現象もあるのではないか と筆者は考えている，たとえば RDS の血中に は非常に多量の可溶性フィブリンモノマー復合 体 (soluble fibrin monomer complex, SFMC) が存在するといらことである。すなわち新生児 の血液は SFMC を作りやすい血液であるとい う印象をもっている。

この論文では，1）小児の FDP の生理的変動. 2）小児の各種疾患におけるFDP. 3）最後に RDS の FDP について紙面のゆるすかぎり述べ ることにする.

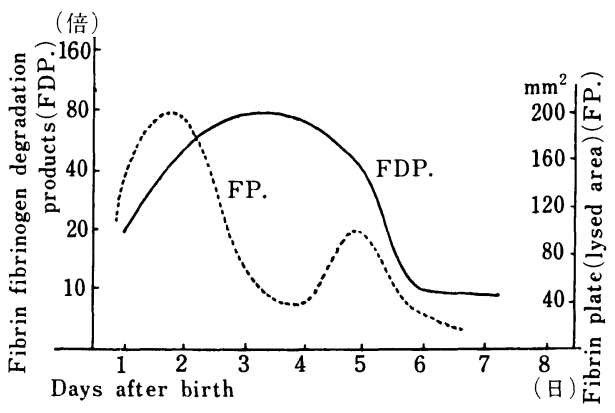

図 1 新生览の線溶活性と $\mathrm{FDP}^{1}$ ). FP: フィブリン標準平板

\section{I. 小児の FDP の生理的変動}

新生児ではプラスミン活性が生理的に上昇し ている. 新生児期のプラスミンの上昇は生後 1 〜2 日目にもっとも著しい.

新生児期のプラスミン上昇の原因として考光 られることは 1) 出生時には一時的に hypoxia の状態となるが，これにより活性が上昇する.

2) 出生時の第 1 呼吸で肺が非常に大きな運動 をする.このために肺から組織アクチベーター が血中に流入する．3）新生児では赤血球が崩 壊し, その処理能力が未熟のために新生児黄疸 となる。この時期の溶血はおそらく線溶活性立 進の一因となっていると考号れる。 上記の 3 種の原因のらち前二者が大きな原因であろら。

図 1 は, 山田 (善) ${ }^{1)}$ が検索した成績で新生児 期の線溶活性と FDP の関係を示した模式図で ある.

この線溶活性の成績はフィブリン平板（標準 フィブリン平板，加熱平板）に新鮮血漿を滴下 して溶解面積を測定する方法, あるいはユーグ
* 慶応義熟大学小児科 荻窪病院特殊血液検査室 
表 1 成熟新生児のプラスミン活性值, HIT 值, $\mathrm{SCT}$ 值, 硫酸プロタミンテストの正常限 界

\begin{tabular}{|c|c|c|}
\hline & \multicolumn{2}{|c|}{ 正 常 限 界 } \\
\hline & 新 生 児 & 成 \\
\hline フィブリン平板法 & & \\
\hline 標準平板法 & $<100 \mathrm{~mm}$ & $<10 \mathrm{~mm}$ \\
\hline 加熱平板法 & $<30 \mathrm{~mm}$ & 0 \\
\hline ユーグロブリン溶解時間值 & $90 \min <$ & $160 \min <$ \\
\hline HIT 值 & $<40 \gamma$ & $<10 \gamma$ \\
\hline SCT 值 & $<80 \gamma$ & $<10 \gamma$ \\
\hline 硫酸プロタミンテスト & $-\sim+$ & - \\
\hline
\end{tabular}

ロブリン溶解時間法などによって得られたもの である。

またFDP は赤血球凝集阻止反応 (Hemagglutination inhibiton test, HIT) によって得られ た成績である。

この模式図は線溶活性立進が生後 $1 \sim 3$ 日目 に認められ, FDP が生後 $2 \sim 4$ 日目に増加して いることを示している.

また図が示すごとく，線溶活性六進に $2 つ の$ ピークが認められる。それは第 1 の大きなピー クと第 2 の小さなピークである。これはフィブ リン平板法でもまたユーグロブリン溶解時間法 でも同様な結果が得られている，第 1 の大きな ピークは，hypoxia，あるいは肺の大きな運動 なぞによる線溶活性充進，第 2 のピークは新生 児期の溶血の影響による線溶六進と現在のとこ ろ筆者は解釈している。しかし FDP を二峰性 に観察することまではできていない.

正常の成熟新生児の線溶活性值, FDP 值, な らびに類縁物質の生理的な限界值は表 1 に示す ごとくである，新生児の FDP を測定する場合 に，HIT で測定するよりも， SCT で検索する 方が若干高值が得られる傾向がある。また正常 新生児でも硫酸プロタミンが陽性となることも ある。

われわれの in vitro の検討2)によればSFMC に対してもっとも特異的に反応するのは硫酸プ ロタミン反応であった. Staphylococcal clumping test $(\mathrm{SCT})^{3) 4)}$ はこれに次いで反応性が強 く, HIT がもっとも反応性が弱かった. 分解過
程から分類した FDP 別によると，SCT の方が 高分子の early FDP に強く反応し，低分子の late FDP には反応せず HIT は late FDP に も反応することが認められた。

以上の結果にもとづけば新生児では，生理的 状態に early FDP がかなり多量に存在しその一 部が SFMC になっていると考苀られる。しか しこれはあくまでも SCT 法, HIT 法, 硫酸プ ロタミンテストの測定成績にもとついた上での 決論であることを断っておきたい，さらに SF $\mathrm{MC}$ を測定する有効な方法が工夫されて新生児 の FDP および類縁物質の実体がより明らかに なることが望まれる。

新生児 FDP 測定の注意：新生児の FDP 検索 をするにあたって注意すべきことは，検体の採 取ならびに処理である，新生览の採血は困難で ある，採血の場合組織液が混入しやすい，股静 脈からの採血ではとくに組織液が混入しやす く, 硫酸プロタミン反応が false positive なる ことがある。われわれの RDS の研究はすべて 臍動脈カテーテルを挿入し，それから検体を採 取してしらべたものである。しかしこの方法は 臍動脈からの点滴静注の必要のある患者以外に 用いることは不可能である，新生児のフィブリ ンモノマーの検査はなかなか大変である.

つぎに検体の処理である。抗プラスミン剂を 注射器に入れて採取したものでなくては正確な FDP 值の検討は不可能である。われわれは， $10^{-2} \mathrm{M}$ トランサミン入り $3.8 \%$ クエン酸ソーダ を $1 / 10$ 容入れて 採血している。 このようにイ ンヒビターを入れても新生児には FDP が増加 していることが証明される。「新生児の FDP 值 は成人とほとんど変らない，FDPが増加してい るという報告があるが，これは採血にインヒビ タ一を用いていないからである」と述べた報 告 ${ }^{5)}$ があ。筆者はこの点とくに注意している が，やはり FDP は新生児期ではある程度增加 していると考えて差し支えないであろう。

\section{II. 小児の各種疾患の FDP の文献 的考察}

FDPの文献的考察を行ならとすれば必然的に 
表 2 小児科領域に打忊る FDP に関する記載

\begin{tabular}{|c|c|c|c|}
\hline 報 告 者 & 疾 & 測 定 方 法 & 成 \\
\hline Hathaway $\left.{ }^{6}\right)$ & 新生児ビールス性疾患 & $\begin{array}{l}\text { immunodifusion } \\
(1 \sim 5 \mathrm{mg} / \mathrm{d} l \text { 以上陽性) }\end{array}$ & $\begin{array}{l}\text { disseminated herpes infection, cyto- } \\
\text { megalic inclusion disease に施行いず } \\
\text { れも陰性 }\end{array}$ \\
\hline Hathaway ${ }^{6)}$ & IRDS & $\begin{array}{l}\text { immunodifusion } \\
(1 \sim 5 \mathrm{mg} / \mathrm{d} l \text { 以上陽性) }\end{array}$ & $\begin{array}{l}12 \text { 例中 } 7 \text { 例陽性 } 15 \mathrm{mg} / \mathrm{d} l \text { 以上を示し } \\
\text { たものが } 2 \text { 例 }\end{array}$ \\
\hline Hathaway $\left.{ }^{6}\right)$ & 子宮内感染 & $\begin{array}{l}\text { immunodifusion } \\
(1 \sim 5 \mathrm{mg} / \mathrm{d} l \text { 以上陽性) }\end{array}$ & 1 例検索結果, 陽性 \\
\hline Hathaway $\left.{ }^{6}\right)$ & Asphyxia & $\begin{array}{l}\text { immunodifusion } \\
(1 \sim 5 \mathrm{mg} / \mathrm{d} l \text { 以上陽性) }\end{array}$ & 1 例検索結果, 陽性 \\
\hline Chessells?) & Asphyxia & HIT. & $\begin{array}{l}9 \text { 例について18検体検索 } 3 \text { 例 } 5 \text { 検体 } \\
\text { 陽性 }\end{array}$ \\
\hline Alebouyeh ${ }^{8)}$ & 新生児敗血症 & immunodifusion & 12 例中 1 例のみ $150 \mathrm{mg} / \mathrm{d} l$ を示した \\
\hline Katz $\left.^{9}\right)$ & $\begin{array}{l}\text { Hemolytic uremic } \\
\text { syndrome }\end{array}$ & HIT & $\begin{array}{l}40 \sim 80 \mu \mathrm{g} / \mathrm{m} l \text { まで上昇しているのが多 } \\
\text { かつた }\end{array}$ \\
\hline 三間屋ほか10) & $\begin{array}{l}\text { Kasabach Merritt } \\
\text { syndrome }\end{array}$ & SCT & 上昇 \\
\hline 村岡ほか11) & 感染・HUS & HIT & やや上昇したものあり $(32 \times \sim 64 \times)$ \\
\hline 山田ほか12) & 交感神経芽細胞腫 & HIT, SCT & HIT $40 \times$, SCT $160 \times$ まで陽性 \\
\hline
\end{tabular}

DIC の文献的考察ということになりかねない が，文献の中の FDP のみに注目して若干をと めてみたのが表 2 である。

FDPの測定成績は小児科領域のみならず他の 領域のものでもそれらの成績の単位が一定して いないことが多く，成績の解釈に苦しむことが 多い.

とくに小児科領域では測定していない場合が 多く，また測定していても単にFDP 陽性，陰 性といら表現がなされていることが多い.今後 さらに正確な表現が統一されることが望まし いまたフィブリンモノマーの測定に至っては 全く記載がないといってよい.

新生児期で FDP に変動がくるのは, 感染症, 特発性呼吸障害症候群, Asphyxia, 重症黄疸な どである。また新生児期を越えて乳児期または それ以後では，Hemolytic uremic syndrome, Kasabach Merritt syndrome, 先天性心疾患, あ るいは悪性腫瘍などがある。

これらの疾患のいづれもFDP を測定するこ とは，診断のため，あるいは治療方針を決定す る一助として重要である。なかでもRDSのFDP
はとくにいろいろの多くの問題を含んでいる.

RDS の症状の軽重, 経過の進展と FDP の消 長との関連性をわれわれは重要視している。つ ぎの項では RDS の FDPについて述べる.

\section{RDS の FDP}

\section{a ) RDS におけるフィブリンモノマーの 生成}

特発性呼吸障害症候群(idiopathic respiratory distress syndrome，IRDS）の成因に関しては, Hypoperfusion 説, Surfactant 欠乏説などの仮 設が提唱されている。 IRDS はいわゆる肺硝子 様膜症 (Hyaline membrane disease) で死亡率 の高い未熟児の疾患であり幾多の研究がなされ てきた．RDSはIRDSよりさらに範囲をひろげ て, 未熟児あるいは成熟新生児の肺出血, atelectasis などをふくめて総括されたものである.

RDS はこのように種々の成因よりなる症候 群であるが原因はいかんともあれいずれも Asphyxic shock の状態に拈ちいることは共通 した現象であろう。

そしてこの Asphyxia のために凝固がえ進し 
表 3 RDS の出血例と非出血例との各種検査の比較

\begin{tabular}{|c|c|c|c|c|c|c|c|}
\hline & Cases & $\begin{array}{l}\text { Prothrombin } \\
\text { time }\end{array}$ & PTT & HIT & SCT & $\begin{array}{l}\text { Ethanol } \\
\text { gel test }\end{array}$ & $\begin{array}{l}\text { Protamine } \\
\text { Sulfate test }\end{array}$ \\
\hline RDS & 5 & 2 & 3 & 0 & 0 & 0 & 1 \\
\hline$\underset{\text { Hemorrhage }}{\text { RDS }}$ & 7 & 6 & 7 & 3 & 7 & 3 & 6 \\
\hline PTT & time & $\begin{array}{l}21 \text { 秒以上 } \\
00 \text { 秒以上 }\end{array}$ & $\begin{array}{l}\text { HIT } \\
\text { SCT }\end{array}$ & & & & \\
\hline
\end{tabular}

線溶が亢進し，その結果としてフィブリンモノ マーおよび FDP が増加してこれらの complex である SFMC が増加することは理解し難いこ とではない。また Asphyxia の場合には Anoxia のための線溶元進が著明であるために，単なる DIC とは若干異なった様相を呈してくることは 当然考えられる。拈とらく，これだけ多量の SFMC が存在するということも他の DIC では なかなか認められないことであろう。

\section{b ) RDS におけるフィブリンモノマーの} 消長

白幡ら ${ }^{13)}$ の検索によれば RDS ではSCT，お よび硫酸プロタミンの成績と, 血液の PH の值 との関係が大であることが示された。すなわ ち，RDS のきわめて末期を除いた成績につい て観察してみると，PH 7.2 以下では，SCT が $320 \gamma$ 以上を示したものが約 $80 \%$ (PH 7.2 以上 では $320 \gamma$ 以上約 $20 \%$ ）で，硫酸プロタミン陽 性例がやはり約 $80 \%$ （PH 7.2 以上では約 30 \%)であった。しかし上記の事実とともに硫酸 プロタミン反応は RDS の末期になると陰性に なることも一つの興味ある事実として見出され ている.

硫酸プロタミン反応の陰転については, 現在 適当な説明が見出されないが凝固克進, 線溶立 進の最後の exhaust した状態がこの反応を陰性 化させることは，このテストを用いる時に注意 しなくてはならないことであろう。

\section{c) RDS におけるフィブリンモノマーの 意義}

Bley114)15) は周生期の Asphyxic shock で死亡 した症例の病理解剖を研究し,この際の肺の硝 子様膜は, 书そらく Asphyxic shock の際に生成
されたフィブリンモノマーによるものであると いら仮説を提唱している.

未熟児にお竹るIRDS の肺硝子様膜も血中に 増量したフィブリンモノマー由来のものである と考えるのも拈とらく当を得たことであろら． しかしなぜ血中のフィブリンモノマーが肺の毛 細血管より肺胞内に渗出してこれが不溶性のポ リマーになるか，他の DIC ではこのよらな特 徵がなぜないのか, 重要な問題である.

フィブリンモノマーが肺硝子様膜として沈着 する原因の一つとしては，拈そらく未熟児の肺 胞壁の局所線溶の欠乏があげられるであろう。 これだけでは十分な説明とはいえないが，現在 これ以上の説明は不可能である。

SFMC が血中に多く存在する状態というのは たしかにきわめて異常な状態である。しかしこ れは生体の最後の防衛機構であろう。すなわち SFMC は凝固充進がおきた場合に，抗トロンビ ン作用を示し，重合作用を抑制するための一つ の産物といってょい.

しかしながら実際にはそのよらな時には出血 がきわめて多いのがわれわれの成績の示す通り である。表 3 はわれわれが検索した RDS の検 索成績のまとめである，RDSで出血傾向が著明 であった群と著明でなかった群とにわけて，プ ロトロンビン時間，PTT，硫酸プロタミンテス ト，エタノールゲルテスト，SCT，HITについ てまとめてみると明らかな差異が見出された。 そして出血傾向を示してた群では, SCT と硫 酸プロタミン反応がもっとも明らかに高值，あ るいは陽性を示していた。すなわち，SFMCが もっとも多量に存在することが示されている. 結局，以上のことを整理して考えると， 
Asphyxia の結果として, 最後の防衛機構である SFMC が多量に作り出されるが，その状態の時 には非常に出血しやすい状態になっておうり， た SFMC 自体も止血に対して抑制的に働いて いるのである。それでこのような状態の時に臨 床的にいかなる治療方針で対処するかというこ とが大変むずかしい問題となってくるが，現在 の筆者の考えは次に述べるようなものである。

\section{FDP と治療}

新生児期には生理的に FDP がある程度増加 していることは先にも述べたごとくである。し かしその程度の FDP の増加でとくに生体に影 響を与えているょらにはみられない。山田 (善) $)^{1)}$ ，第XIII 因子の研究のためにも分婏前 の母親拉よび，出生後の新生児にイプシロン， トランサミンを与えて FDPを減少させてみた. しかしそれでとくに変った問題が生じたわけで もなし，また新生児黄疸にも影響は与えなかっ た。多少の FDP の増加ではそれ自体で影響は 少ないのであろう。

一方多量の FDP，フィブリンモノマーが血中 に見出される場合には，まずその原因疾患の治 療を行ならことに全力をそそぐべきである。

たと光ば，RDSでは，酸素の投与，Resusitation，あるいは acidosis の治療をまづ行ならべ きである。また Hemolytic uremic syndrome で は腹膜灌流を行ならべきであろう。 acidosis を 改善すること，あるいは腎機能を改善すること で凝固充進, 線溶充進は, おのつから改善の方 向に向 5 .

さてそれらに加えてさらに何をわれわれはす べきかということになってくる.

われわれの経験では, FDP, SFMC が多量に 証明される RDS の症例にへパリンを投与した 場合に SFMC は消失した。しかし，時に出血 傾向がむしろ増加した場合がみられた。早期の ヘパリン療法は有効であるが，末期には無効， むしろ有害である。

また線溶の亢進が著明で出血傾向が著しい場 合には，ペパリン療法とともに抗プラスミン剤 を使用することを，RDS で検討しつつあるが
その決論を公表する段階ではない。

慶大小览科学教空 市橋保雄教授の御校閲を深謝 致します。

\section{文献}

1) 山田善三郎：新生児期の線維素溶解 (線溶) 活 性と第 XIII 因子に関与る研究, 第 1 編, 新生児 期の 線溶活性と線維素分解産物の検討. 日小 誌． 75； 294，1971. 第 2 編，新生児期の第 XIII 因子と線溶活性との関係。日小誌， 75； 297, 1971.

2）山田兼雄：新生児の FDP, FDP シンポジゥム 司会 安部英, 福武勝博, 第 34 回日本血液学会 総会. 1972年 4 月.

3) Hawiger, J. et al.: Measurment of fibrinogen and fibrin degradation products in serum dy staphylococcal clumping test. J. Lab. Clin. Med., 75; 93, 1970.

4) 中沢真平注か: Staphylococcal clumping test （SCT）の検討捛よびその臨床的価值. 臨床血 液， 13；363，1972.

5) Chessels, J. M.: The sigmificance of fibrin degradation products in the blood of normal infants. Biol. Neonat., 17; 219, 1971.

6) Hathaway, W. E. et al: Desseminated intravascular coagulation in the nowborn. Pediatrics, 48; 233, 1969.

7) Chessells, J. M. et al: Coagulation studies in severe birth asphixia. Arch. Dis. Childhood., 46; 253, 1971.

8) Alebouyeh, M. et al: Incidence of disseminated intravascular coagulation in the course of septicemia in newborn infants. Z. Kinderheilk., 109; 326, 1971.

9) Katz, J. et al.: Coagulation finding in the hemolytic-uremic syndrome of infancy: Similavity to hyeracute renal allograft rejection J. Pediat., 78; 426, 1971.

10）三間屋純一注か：Giant haemangioma with coagulation abnormalities (Kasabach Merritt syndrome) の 3 症例。第14回日本臨床血液学会 総会。昭和 47 年 10 月.

11）村岡伸一注か：DICの成因と治療について, 小児科診療， 35；1，1972.

12）山田兼雄ほか: Consumption coagulopathy を 示した神経芽細胞腫の 1 例， 日小児，76；358， 1972.

13）白幡 聡活か：未熟児の呼吸障害症候群比括訬 る FDP の検討. 第14回臨床血液学会総会, 昭 
和 47 年 10 月.

14) Bleyl, V. et al.: Pulmonale hyline Membranen and perinataler Kreislanfschock. Virchows Arch. Abt. A. Path. Anat., 348; 187, 1969.
15) Bleyl, V.: Schock, Disseminierte intravasale Gerinnung and Idiopatisches Atemnotsyndrom der Neugeborenen XIII International Congress of Pediatrics Wien, 1971.

急地医芜のための腿底検查法 全身疾患の眼底所見 日本大学助教授 松井瑞夫著 - B 5 頁110 図20 写真15 原色図82 定価 8,200円（干140）

〈主要目次〉直像検眼鏡の原理と使い方 /蛍光眼底撮影法 /正常眼底 / 網膜 出血 /網膜の白玟 / 乳頭浮腫 /血液疾患 / 膠原病 / 網膜色素線状 / 外賃性 網膜血管症 血圧方進に伴う眼底变化 /本態性高血圧症の眼底所見 / 腎疾 患の眼底所見 / 糖尿病の眼底所見 振替東京 105704 /東京医学社 